\title{
Aquatic biota response to climate and habitat changes from the Valdai Glaciation to the Meghalayan (Serteya region, Western Dvina Lakeland)
}

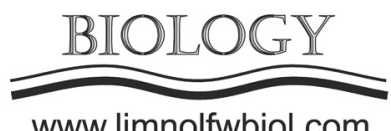

\author{
Płóciennik M. ${ }^{1 *}$, Mroczkowska A. ${ }^{2,3}$, Kittel P. ${ }^{3}$, Pawłowski D. ${ }^{4}$, Kurzawska A. ${ }^{5}$, \\ Danger M. ${ }^{6}$, Maigrot Y. ${ }^{6}$, Rzodkiewicz M. ${ }^{7}$, Wieckowska-Lüth M. ${ }^{8}$, Okupny D. ${ }^{9}$, \\ Kruk A. ${ }^{10}$, Luoto T.P. ${ }^{11}$, Kotrys B. ${ }^{12}$, Nazarova L. ${ }^{13}$, Syrykh L. ${ }^{14}$, Szmańda J. ${ }^{15}$, \\ Dolbunova E. ${ }^{16,17}$, Mazurkevich A. ${ }^{16}$
}

${ }^{1}$ University of Lodz, Dept. of Invert. Zool. and Hydrobiol., 12/16 Banacha St., Lodz 90-237, Poland

${ }^{2}$ Polish Academy of Sciences, Past Landsc. Dynam. Lab., Ins. of Geogr. and Spat. Org., 51/55 Twarda St., Warsaw 00-818, Poland

${ }^{3}$ University of Lodz, Dept. of Geomorph. and Palaeogeog., 88 Narutowicza St., Lodz 90-139, Poland

${ }^{4}$ Adam Mickiewicz University, Inst. of Geol., 12 Krygowskiego St., 61-680 Poznan, Poland

${ }^{5}$ Polish Academy of Sciences, Inst. of Archaeo. and Ethnol., Poznań, Poland

${ }^{6}$ UMR 8215 Trajectoires, CNRS-Université Paris 1 Panthéon - Sorbonne, Nanterre, France

${ }^{7}$ Adam Mickiewicz University, Lab. of Biogeochem., 12 Krygowskiego St., 61-680 Poznan, Poland

${ }^{8}$ University of Kiel, Archaeobot. and Palynol. Lab., Inst. of Prehist. and Protohist. Archaeol., Germany

${ }^{9}$ University of Szczecin, Inst. of Mar. and Envir. Scienc., Szczecin, Poland

${ }^{10}$ University of Lodz, Dept. of Ecol. and Vertebr. Zool. 12/16 Banacha St., 90-237 Lodz, Poland

${ }^{11}$ University of Helsinki, Ecosys. and Envir. Res. Prog., 15140 Lahti, Finland

12 Pomeranian Branch, Polish Geological Institute - National Research Institute, 20 Wieniawskiego St., Szczecin 71-130, Poland

${ }^{13}$ Potsdam University, Inst. of Geosc., Potsdam, 14476, Germany

${ }^{14}$ Herzen State Pedagogical University, St. Petersburg, 191186 Russia

${ }^{15}$ Pedagogical University of Cracow, Inst. of Geogr., Cracow, Poland

${ }^{16}$ The State Hermitage Museum, 34 Dvortsovaya Naberezhnaya St., 190000 St. Petersburg, Russia

${ }^{17}$ The British Museum, London, UK

\begin{abstract}
The Serteyka River valley is one of the most important archaeological localities in NorthWestern Russia. The State Hermitage Museum has conducted research in Serteya since the 1970s. The pile-dwelling remnants located within the Great Serteya Palaeolake Basin (GSPB) are the most prominent excavation. The investigation using precise underwater techniques recovered many exceptional remains of the Neolithic settlement that were preserved below the groundwater level in biogenic deposits. The large-scale studies focused till now primarily on relicts of the human settlement and only scarce environmental data were available before the last decade. A broad environmental archaelogical project using cores of organic deposits has been conducted since 2016 in the framework of Polish-Russian cooperation. The $8 \mathrm{~m}$ long STIIa core from the deepest lake point has been investigated. It gives a full sequence of the lake history from the Late Valdai Glaciation to the Middle Ages. Multi-proxy analysis of the STIIa core aims at the reconstruction of regional and local habitat conditions (e.g. climate, hydrology, trophic state, water chemistry, and plant communities) at the lake side during the MIS1.
\end{abstract}

Keywords: Climate change, quantitative reconstruction, lake-river system, pile-dwelling

\section{Introduction and Methods}

To continue the preliminary palaeoecological research conducted by Kul'kova M.A., Savel'eva L.A. and Tarasov et al. (2019) at the GSPB, the Polish-Russian project started in 2016 aims at a high resolution multiproxy reconstruction of palaeoecological conditions and of the regional climate from the Late Valdai Glaciation to the Middle Ages (Kittel et al. 2018) at GSPB. The project will provide the environmental background for the history of human settlement activity since the Palaeolithic onwards.

The age-depth model is based on 12 AMS radiocarbon dates. Palaeo-environmental reconstructions are based on geochemical, pollen, plant macrofossils, diatom, Cladocera, Chironomidae, malacological and fish remains analyses. 


\section{Results}

The continuous accumulation of coarse-detritus gyttia was replaced by the fluvial overbank deposition after $3.6 \mathrm{ka}$ cal. BP, probably as late as in the Early Middle Ages.

Plant macrofossils are recorded from $449 \mathrm{~cm}$ onwards. From $449 \mathrm{~cm}$ to $194 \mathrm{~cm}$, fruits and seeds of helophytes and hydrophytes appear. From $194 \mathrm{~cm}$ to 96 $\mathrm{cm}$, communities of aquatic macrophytes, amphiphytes and helophytes increase including Trapa natans fruits. No or very few diatoms were found below $431 \mathrm{~cm}$. From $431 \mathrm{~cm}$ to the top of the core, tychoplanktonic diatom taxa are recorded.

Between 795 and $564 \mathrm{~cm}$, the concentration of Cladocera, Mollusca and Chironomdae remains is low. Above $564 \mathrm{~cm}$, the abundance of invertebrates increases and littoral taxa associated with macrophytes dominate. Among Cladocera, pelagic taxa prevail. Above $448 \mathrm{~cm}$, the Cladocera remains concentration exceeds 12800 specimens $/ \mathrm{cm}^{3}$. At the same time, the number of pelagic taxa fluctuates and decreases above $118 \mathrm{~cm}$. Mollusc remains are rather scarce along the core sequence. They were recorded along the core samples with fine detritus gyttia $(151-175 \mathrm{~cm})$. Their appearance is strictly associated with a rise of aquatic macrophytes (presence of Valvata cristata and Bithynia operculum taxa- indicative of overgrown places). The other molluscs comprise species preferring permanent water bodies and are of wide ecological preferences (Bithynia tentaculata, Valvata piscinalis, Radix balthica, Unionidae, Pisidium subtruncatum).

A total of 1179 fish remains were found in the core samples. 103 fish remains were identified to the taxa level. Perca fluviatilis, cyprinids and Esox lucius are the dominant taxa. All remains belong to fish that are quite small, not exceeding $10 \mathrm{~cm}$ in total length.

\section{Discussion and conclusions}

Our results indicate that before $9.3 \mathrm{ka}$ cal. BP climatic conditions were too cold for development of ample aquatic vegetation as well as abundant invertebrate and fish communities. During the Holocene, an ecosystem composed mainly of plant and animal taxa typical for eutrophic conditions development emerged. Plant communities were dominated by warmadapted shallow water taxa, such as Trapa natans, but high abundances of pelagic Cladocera indicate a relatively high water level. The productive ecosystem was favourable for human fisheries and a gatherer economy.

\section{Acknowledgements}

The research project has been financed by grant from The Polish National Science Centre based on the decision No. "DEC-2017/25/B/HS3/00274".

\section{References}

Kittel P., Mazurkevich A., Dolbunova E. et al. 2018. The geomorphological conditions of the Neolithic pile-dwelling Serteya II site, Western Russia. Acta Geographica Lodziensia 107: 191-213.

Tarasov P.E., Savelieva L.A., Long T., Leipe C. 2019. Postglacial vegetation and climate history and traces of early human impact and agriculture in the present-day cool mixed forest zone of European Russia. Quaternary International 516: $21-41$. 